\title{
KUALITAS LAPORAN KEUANGAN DAN PENGENDALIAN INTERNAL, TERHADAP EFISIENSI INVESTASI
}

\author{
I Made Pradana Adiputra \\ adiputraundiksha@gmail.com \\ S3 Program Pascasarjana Ilmu Akuntansi Fakultas Ekonomi dan Bisnis \\ Universitas Indonesia (UI) Depok \\ Sidharta Utama \\ Sylvia Veronica NP. Siregar \\ Fakultas Ekonomi dan Bisnis Universitas Indonesia (UI) Depok
}

\begin{abstract}
This study aims to analyze the relationship between the quality of financial statements and over/ underinvestment and the influence of the quality of financial statements on over/under-investment with the disclosure of the level of internal control in listed and non-listed state-owned companies in Indonesia. The research sample was listed and non-listed BUMN in Indonesia with 208 firms-years during 2011-2016 with linear regression analysis using the SPSS program. The regression test results show that there is support for the hypothesis of this study, namely that the quality of financial statements negatively affects over/under-investment and the effect of the quality of financial statements on over/under-investment is stronger in SOEs that disclose their internal controls. To strengthen the results of the research, additional testing was conducted to analyze the differences between listed SOEs and non-listed SOEs. The results show that listed SOEs have more explanatory power on the effect of the quality of financial statements on over/under-investment than non-listed SOEs. That is because listed SOEs must also follow capital market regulations (Indonesia Stock Exchange) and market mechanisms that relate to investors and other external parties who have an interest in the operation (performance) of these SOEs.
\end{abstract}

Key words: quality of financial statements, internal control, efficiency investments, SOE

\begin{abstract}
ABSTRAK
Penelitian ini bertujuan untuk menganalisis hubungan kualitas laporan keuangan dan over/underinvestment serta adanya pengaruh kualitas laporan keuangan terhadap over/under-investment dengan adanya pengungkapan tingkat pengendalian internal pada perusahaan BUMN yang listed dan non listed di Indonesia. Sampel penelitian adalah BUMN listed dan non-listed di Indonesia sebanyak 208 firms-years selama tahun 2011-2016 dengan analisis regresi linier menggunakan program SPSS. Hasil pengujian regresi menunjukkan adanya dukungan terhadap hipotesis penelitian ini yaitu bahwa kualitas laporan keuangan berpengaruh negatif terhadap over/under-investment dan pengaruh kualitas laporan keuangan terhadap over/under-investment lebih kuat pada BUMN yang mengungkapkan pengendalian internalnya. Untuk memperkuat hasil penelitian dilakukan pengujian tambahan untuk menganalisis perbedaan antara BUMN listed dan BUMN yang non-listed. Hasilnya menunjukkan bahwa BUMN listed lebih memiliki kekuatan penjelas pada pengaruh kualitas laporan keuangan terhadap over/under-investment dibandingkan BUMN non-listed. Hal tersebut dikarenakan BUMN listed juga harus mengikuti regulasi pasar modal (BEI) dan mekanisme pasar yang berhubungan dengan investor dan pihak luar lainnya yang berkepentingan dengan operasional (kinerja) BUMN tersebut.
\end{abstract}

Kata kunci: kualitas laporan keuangan; pengendalian internal; efisiensi investasi; BUMN 


\section{PENDAHULUAN}

Kualitas laporan keuangan merupakan hal penting bagi perusahaan untuk menunjukkan kinerjanya selama periode tertentu dan bermanfaat bagi pemangku kepentingan perusahaan. Laporan keuangan memberikan informasi bagi pengguna sehingga diharapkan tidak terjadi kesenjangan informasi. Watts dan Zimmerman (1986) mengemukakan bahwa laporan keuangan yang berkualitas dapat mengurangi kesenjangan informasi (asimetri informasi) diantara pemangku kepentingan perusahaan seperti yang digambarkan teori keagenan. Terjadinya kesenjangan informasi tersebut dapat menimbulkan konflik kepentingan dan perilaku oportunistik manajer yang kemungkinan akan berdampak pada terjadinya eksploitasi sumber daya perusahaan secara tidak terkendali sehingga perusahaan akan berada pada kondisi kesulitan keuangan dan tidak dapat melakukan investasi yang efisien.

Kualitas akuntansi melalui pelaporan keuangan memang berpengaruh besar terhadap investasi yang efisien, terlebih hal tersebut akan berhubungan dengan risiko yang ada dalam setiap pengambilan keputusan perusahaan (Chung et al., 2013). Idealnya, di pasar keuangan di mana asimetri informasi tidak ada antara perusahaan, manajer dan investor eksternal, perusahaan dapat secara optimal berinvestasi dalam proyek-proyek menguntungkan (Houcine, 2017). Mengurangi adverse selection dan moral hazard merupakan cara agar manajer dapat mengidentifikasi peluang investasi yang lebih baik melalui kualitas pelaporan keuangan sehingga dapat meningkatkan efisiensi investasi (Gomariz dan Ballesta, 2014). Bahkan peran forecast analysis sangat menentukan kualitas pelaporan keuangan terhadap efisiensi investasi (Chen et al., 2017).

Pada penelitian yang dilakukan oleh Biddle et al. (2009) menunjukkan bahwa perusahaan dengan kualitas pelaporan keuangan yang rendah pada under-invest (overinvest) ketika perusahaan memiliki ke- terbatasan keuangan (tanpa keterbatasan keuangan. Gomariz dan Ballesta (2014) menemukan bahwa kualitas pelaporan keuangan meringankan masalah over-investasi. Keandalan informasi keuangan akan meningkatkan efisiensi investasi (Chung et al., 2013; Houcine, 2017).

Cheng et al. (2013) menyatakan bahwa hasil penelitian tersebut menjadi penting untuk menunjukkan bahwa kualitas pelaporan keuangan perusahaan memiliki asosiasi dengan efisiensi investasi secara riil. Akan tetapi disebutkannya bahwa penelitian tersebut tidak membangun hubungan kausal terhadap asosiasi tersebut. Oleh Cheng et al. (2013) melanjutkan penelitian Biddle et al. (2009) tersebut dengan menguji hubungan kausal antara kualitas pelaporan keuangan dan efisiensi investasi dengan mengambil keuntungan dari ketentuan Sarbanex-Oxley (SOX) Act yang mengharuskan perusahaan untuk mengungkapkan adanya kelemahan pengendalian internal dalam pelaporan keuangan seperti yang ditentukan pada US Conggres tahun 2002.

Jaehong et al. (2016) memberikan argumentasi sehubungan adanya kelemahan pengendalian akuntansi internal dan inefisiensi investasi, bahwa kualitas akuntansi ditentukan oleh sistem pengendalian internal yang lemah. Menurutnya, secara konseptual sistem pengendalian akuntansi internal yang buruk adalah dasar untuk pelaporan keuangan berkualitas rendah. Hal tersebut karena pengendalian internal yang lemah tidak dapat mencegah kesalahan prosedural dan estimasi, serta manajemen laba secara oportunistik oleh manajer. Sejalan dengan itu, penelitian Ji et al. (2017) membuktikan bahwa lemahnya pengendalian internal akan berpengaruh terhadap kualitas laba. Chalmers et al. (2018) melakukan review beberapa penelitian tentang pengendalian internal menemukan bahwa kualitas pengendalian internal dapat memiliki efek yang signifikan pada pengambilan keputusan pengguna informasi keuangan. Adanya kelemahan pengendalian internal menunjukkan adanya masalah 
informasi dalam sistem pelaporan keuangan perusahaan, sehingga diperkirakan bahwa perusahaan dengan pengungkapan pengendalian internal yang lemah akan menunjukkan adanya perilaku investasi yang tidak efisien (Cheng et al., 2013; Jaehong et al., 2016). Dengan demikian, perusahaan harus menunjukkan kualitas pelaporan keuangannya pada periode sebelum dan setelah pengungkapan pengendalian internal perusahaan sehingga akan berdampak pada keputusan investasi perusahaan. Pengendalian internal yang lemah dapat meningkatkan asimetri informasi dan mengarah pada terjadinya inefisiensi investasi (Cheng et al., 2013; Jaehong et al., 2016).

Dihubungkan dengan masalah pengendalian internal dikemukan oleh PCAOB (2004), Donaldson, 2005 (dalam AshbaughSkaife et al., 2008) bahwa keandalan laporan keuangan diklaim merupakan fungsi dari efektivitas pengendalian internal kontrol perusahaan. Beberapa penelitian menyebutkan temuan bahwa pengendalian internal yang lemah akan berdampak terhadap kualitas akrual sebagai komponen penting laporan keuangan yang reliabel (Hogan dan Wilkins, 2005; Bedard, 2006; Doyle et al., 2007; Jaehong et al., 2016). Ashbaugh-Skaife et al. (2008) menyatakan bahwa perusahaan yang memiliki pengendalian internal yang lemah, maka manajer kurang mampu untuk menentukan jumlah akrual yang handal, dan konsekuensi dari kekeliruan yang tidak disengaja tersebut menyebabkan informasi keuangan lebih noise dan kurang dapat diandalkan. Selain itu, manajer perusahaan dengan pengendalian internal yang lemah dapat lebih mudah mengesampingkan pengendalian dan sengaja menyiapkan perkiraan bias akrual yang memfasilitasi pemenuhan tujuan pelaporan keuangan secara oportunistik. Lambert et al. (2007) menyatakan bahwa kualitas pelaporan keuangan meningkat seiring dengan meningkatnya pengendalian internal perusahaan. Regulasi pengendalian internal membatasi diskresi manajerial untuk melakukan perubahan kualitas laporan keuangan dan keinfor- matifan laporan keuangan (Altamuro dan Beatty, 2010). Pengungkapan lemahnya pengendalian internal kepada pemangku kepentingan mengungkapkan adanya defisiensi pengendalian internal yang dianggap sebagai berita buruk bagi para pemangku kepentingan (Ji et al., 2017)

Penyimpangan investasi dari tingkat yang optimal dapat terjadi dalam bentuk under investment dan over investment. Dengan meningkatnya kualitas laporan keuangan, kesenjangan informasi antara manajer dan investor diekspektasi menurun dan selanjutnya menurunkan adverse selection. Kesenjangan informasi yang semakin kecil mendorong harga pasar saham menuju nilai sebenarnya (intrinsik) karena memperkecil kemungkinan harga saham dinilai terlalu rendah (underpriced) atau terlalu tinggi (overpriced). Kondisi ini menurunkan kecenderungan manajer melakukan over investment.

Di sisi lain, investor yang percaya bahwa laporan keuangan perusahaan menggambarkan kondisi ekonomi yang sesungguhnya memperbaiki penilaian mereka tentang tingkat risiko perusahaan dan bersedia menawarkan biaya modal yang lebih rendah. Perusahaan yang tadinya mengalami kesulitan pendanaan kini memperoleh kesempatan mendapatkan tambahan modal karena biaya modal lebih rendah. Situasi ini akan berdampak pada menurunnya under investment. Temuan Cheng et al. (2013) dan Jaehong et al. (2016) menunjukkan bahwa penyimpangan investasi dari nilai optimal dipengaruhi oleh ketersediaan sumber keuangan (financial resources). Lebih jauh ditemukan bahwa perusahaan yang memiliki sumber keuangan yang melimpah (terbatas) cenderung melakukan investasi secara berlebihan over (under) investment.

Sehubungan dengan biaya modal, Ashbaugh-Skaife et al. (2009) dan Dhaliwal et al. (2011) mendokumentasikan bahwa pada perusahaan dengan pengendalian internal yang rendah akan memiliki biaya modal yang lebih tinggi dibandingkan aspek yang lain yang dapat dikendalikan 
oleh perusahaan (control firms). Cheng et al. (2013) mengemukakan bahwa peningkatan biaya modal akan dihubungkan dengan pengendalian internal yang lemah pada perusahaan yang terbatas keuangannya untuk melakukan under-invest, dibandingkan dengan financially constrained control firms secara equal, karena perusahaan seperti itu memiliki banyak kesulitan untuk meningkatkan modal yang dibutuhkan untuk mendanai proyek perusahaan.

Apabila melihat pengaturan pengendalian internal pada perusahaan yang go public di Indonesia sebenarnya telah diatur dalam Peraturan Nomor VIII.G.11 tentang tanggung jawab direksi atas laporan keuangan oleh Badan Pengawas Pasar Modal dan Lembaga Keuangan (Bapepam-LK) pada tahun 2003. Peraturan tersebut mengharuskan direksi perusahaan membuat pernyataan tertulis diatas meterai bahwa sistem pengendalian internal perusahaan merupakan tanggung jawab mereka sepenuhnya. Peraturan yang diterbitkan oleh Bapepam-LK ini dapat dipandang sebagai respon otoritas pasar modal Indonesia saat itu atas terbitnya Sarbanes and Oxley Act (SOX) di Amerika Serikat tahun 2002, khususnya Seksi 302 dan Seksi 404. Seksi 302 mengharuskan direksi menyatakan secara tertulis bahwa mereka bertanggung jawab atas laporan keuangan perusahaan, termasuk pengendalian internal, dan setiap perubahan material atas pengendalian internal (Doyle et al., 2007). Sementara, Seksi 404 mewajibkan manajemen menerbitkan laporan tentang pengendalian internal terhadap pelaporan keuangan yang disertifikasi auditor independen.

Penelitian ini dilakukan sebagai pengembangan atas temuan utama penelitian Ashbaugh-Skaife et al. (2008), Biddle et al. (2009) dan Butar Butar (2015) dengan memadukan temuan penelitian Cheng et al. (2013), Chung et al. (2013), Gomariz dan Ballesta (2014), Houcine (2017) dan Jaehong et al. (2016). Dasar pertimbangan secara logika empiris bahwa kualitas laporan keuangan akan berpengaruh terhadap ke- putusan investasi perusahaan. Kualitas laporan keuangan yang tinggi dapat terwujud melalui adanya pengendalian internal yang baik guna menurunkan adanya asimetri informasi antara manajemen dan pihak yang berkepentingan sehingga berdampak pada putusan melakukan efisiensi investasi.

Pengendalian internal dapat meningkatkan kualitas laporan keuangan dan menurunkan kesenjangan informasi antara manajer dan pemegang saham. Kualitas laporan keuangan yang baik akan menekan moral hazard dan adverse selection serta mendorong terciptanya keselarasan antara kepentingan manajer dan pemegang saham (Jensen dan Meckling, 1976). Hal tersebut bila terjadi maka manajer diekspektasi melakukan investasi hanya pada proyekproyek yang memberikan keuntungan kepada pemegang saham dan tidak lagi berinvestasi secara over investment atau under investment pada proyek yang memiliki net present value positif (Biddle et al., 2009). Investasi yang dilakukan perusahaan merupakan investasi yang optimal, dimana over investment dan under investment mengalami penurunan. Biddle et al. (2009) menyatakan bahwa dorongan manajer melakukan over atau under investment tergantung pada ketersediaan sumber daya keuangan. Kualitas laporan keuangan akan menentukan perusahaan melakukan efisiensi investasi dengan adanya faktor pengendalian internal dan kendala keuangan perusahaan.

Penelitian ini akan menggunakan sampel perusahaan BUMN di Indonesia. Fontanella et al. (2014) menyatakan bahwa perusahaan BUMN (listed dan non listed) yang memiliki karakteristik berbeda (unique). Pertama, karena BUMN seluruh sahamnya atau sedikitnya $51 \%$ dimiliki oleh pemerintah maka akan menghadapi intervensi yang lebih besar dari pemerintah dibandingkan perusahaan non BUMN. Kedua, sebagian besar BUMN bergerak dalam bidang industri yang strategis. Ketiga, jika dilihat dari aspek regulasi, 
BUMN lebih highly regulated dibandingkan perusahaan non BUMN. BUMN menjadi objek sejumlah aturan perundang-undangan karena BUMN mengelola kekayaan negara yang dipisahkan dan sebagian besar merupakan industri yang sifatnya strategis. Keempat, BUMN (non Perum) menghadapi tekanan yang besar untuk menghasilkan laba.

Sepengetahuan penulis belum ada penelitian yang secara khusus menguji tentang kualitas laporan keuangan terhadap efisiensi investasi dengan adanya pertimbangan faktor pengendalian internal dan kendala keuangan pada perusahaan jenis BUMN. Beberapa penelitian terdahulu yang mengambil sampel perusahaan BUMN beberapa dintaranya menguji tentang kualitas laba, kualitas informasi akuntansi dan manajemen laba yang dapat dikaitkan dengan aspek pengendalian internal yang bersumber dari tata kelola perusahaan. Literatur menunjukkan kualitas laba pada perusahaan yang dimiliki pemerintah (state owned enterprise/SOE) lebih rendah daripada perusahaan non SOE (Liu et al., 2014). Penelitian Liu et al. (2014) yang membandingkan kualitas laba SOE listed dan perusahaan non SOE listed di China menemukan bahwa SOE listed melakukan lebih banyak earning smoothing, earning management dan tidak mengakui kerugian secara tepat waktu dibandingkan non SOE listed. Disamping itu juga ditemukan SOE listed mempunyai nilai discretionary accrual yang lebih besar dibandingkan non SOE listed. Borisova et al. (2012) yang meneliti pada sampel perusahaan di European Union menemukan perusahaan yang dimiliki oleh pemerintah memiliki tata kelola (governance) dan kualitas informasi akuntansi yang lebih buruk.

Berdasarkan Keputusan Menteri Negara Badan Usaha Milik Negara Nomor: Per-01/MBU/2011 tentang Penerapan Tata Kelola Perusahaan Yang Baik (Good Corporate Governance) pada BUMN pada Pasal 2 menyebutkan kewajiban BUMN menerapkan GCG, direksi menyusun GCG manual yang diantaranya memuat sistem pengendalian intern. Indikator pelaksanaan sistem pengendalian intern ini akan diperiksa dan diungkapkan melalui BPK melalui Ikhtisar Hasil Pemeriksaan Semester (IHPS) setiap tahun.

Beberapa hasil pemeriksaan BPK pada BUMN sesuai dokumen IHPS II/2015 menunjukkan masih lemahnya sistem pengendalian internal perusahaan pada 21 perusahaan BUMN. Kelemahan tersebut diantaranya meliputi Standar Operasional Prosedur (SOP), pelaksanaan kebijakan yang mengakibatkan hilangnya potensi penerimaan, SOP yang tidak ditaati dan lain-lain (Anugrah, 2016).

Berdasarkan hal tersebut diatas, tujuan penelitian ini untuk menganalisis dampak kualitas laporan keuangan terhadap efisiensi investasi dengan mempertimbangkan faktor pengendalian internal dan keterbatasan keuangan pada perusahaan BUMN di Indonesia baik yang listed maupun nonlisted. Pada kebanyakan penelitian, konteks tersebut dilakukan pada perusahaan privat yang listed di bursa efek. Membandingkan perusahaan BUMN listed dan non listed dapat dilakukan karena BUMN menjadi objek regulasi yang sama.

\section{TINJAUAN TEORETIS \\ Teori Agensi}

Jensen dan Meckling (1976) mendefinisikan suatu hubungan agensi sebagai suatu kontrak antara satu atau lebih principal yang meminta orang lain (agent) untuk melakukan beberapa pelayanan untuk kepentingannya yang memasukkan pendelegasian beberapa kewenangan pembuatan keputusan untuk agen. Dalam kontrak antara manajer dengan para pemegang saham maka manajer dilihat sebagai agen dan para pemegang saham dilihat sebagai principal. Pembuatan kontrak yang tepat untuk menyelaraskan kepentingan agen dan pemilik dalam hal terjadi konflik kepentingan merupakan inti dari teori keagenan (Scott, 2009). Oleh karena itu prinsipal perlu merancang sistem pe- 
ngendalian yang memonitor perilaku agen sehingga menghalangi tindakan yang meningkatkan kekayaan agen dengan cara mengorbankan kepentingan prinsipal. Pengendalian merupakan salah satu komponen dalam GCG. Kualitas pengawasan yang baik dapat menurunkan perilaku oportunistik yang dilakukan oleh manajer. Melalui pelaporan dan pengungkapan keuangan berpotensi penting bagi manajemen untuk mengomunikasikan kinerja dan tata kelola perusahaan kepada investor luar (Healy dan Palepu, 2001).

BUMN yang sedikitnya 51\% dimiliki oleh pemerintah maka akan menghadapi intervensi yang lebih besar dari pemerintah dibandingkan perusahaan non BUMN. Apabila dilihat dari aspek regulasi, BUMN lebih highly regulated dibandingkan perusahaan non BUMN. BUMN menjadi objek sejumlah aturan perundang-undangan karena BUMN mengelola kekayaan negara yang dipisahkan dan sebagian besar merupakan industri yang sifatnya strategis. Sehubungan dengan teori agensi bahwa kondisi pada BUMN yang listed dan nonlisted tentu saja berbeda. Selain terikat dengan regulasi yang ketat dari pemerintah, khususnya BUMN yang listed menghadapi tuntutan regulasi dari BEI dan sistem pasar modal sehingga kecenderungan tersebut berbeda dengan BUMN yang non-listed. Masalah keagenan yaitu hubungan principal dan agent dalam kedua kondisi tersebut tentu juga akan mengalami perbedaan.

\section{Badan Usaha Milik Negara (BUMN)}

Menurut Undang-Undang Nomor 19 tahun 2003 tentang Badan usaha Miliki Negara, Badan Usaha Milik Negara (BU$\mathrm{MN}$ ) merupakan badan usaha yang seluruh atau sebagian besar modalnya dimiliki oleh negara melalui penyertaan modal secara langsung yang berasal dari kekayaan negara yang dipisahkan. Penyertaan modal negara dalam rangka pendirian atau penyertaan pada BUMN bersumber dari: Anggaran Pendapatan dan Belanja Negara, kapitalisasi cadangan dan sumber lainnya.
Disamping itu BUMN juga harus mematuhi Undang-Undang Nomor 17 tahun 2003 tentang Keuangan Negara. Hal ini disebabkan karena penyertaan modal yang dilakukan pemerintah pada BUMN bersumber dari keuangan negara yang dipisahkan. Khusus untuk BUMN yang berbentuk Perseroan Terbatas juga harus mengikuti peraturan perundangan yang mengaturnya seperti Undang-Undang No. 40 tahun 2007 tentang Perseroan Terbatas dan peraturan-peraturan lainnya. Banyaknya aturan yang mendasari dan mengawasi pengelolaan BUMN ini menunjukkan bahwa BUMN merupakan perusahaan yang highly regulated dibandingkan perusahaan lainnya.

Badan Pemeriksa Keuangan RI menyatakan bahwa BUMN mempunyai kewajiban untuk menetapkan suatu sistem pengendalian intern (SPI) yang efektif untuk mengamankan investasi dan aset perusahaan (www.bpk.go.id). Penerapan SPI yang efektif dan pengelolaan risiko perusahaan secara terpadu menjadi sangat penting mengingat jumlah aset negara yang dikelola BUMN sangat signifikan dalam era globalisasi dengan terjadinya perubahan lingkungan bisnis yang sangat cepat.

\section{Kualitas Laporan Keuangan dan Efisiensi Investasi}

Menurut teori neo-klasik, pengaruh investasi terhadap nilai perusahaan dapat terjadi jika biaya marjinal lebih rendah dari manfaat (benefit) marjinal investasi (Abel 1983 (dalam Biddle et al., 2009)). Keuntungan marjinal dapat diperoleh jika perusahaan melakukan investasi pada proyek-proyek yang memiliki net present value yang positif sehingga dapat meningkatkan nilai perusahaan dan memberikan return bagi investor.

Terjadinya asimetri informasi atau kesenjangan informasi dapat menyebabkan investasi berjalan tidak optimal (Jensen dan Meckling 1976; Jensen 1986; Blanchard et al. 1994). Ketika kualitas akuntansi tinggi, asimetri informasi diharapkan menjadi 
rendah, mengurangi sensitivitas investasi terhadap arus kas (atau meningkatkan kemampuan perusahaan untuk melakukan investasi) (Beatty et al., 2010). Kualitas akuntansi berhubungan dengan efisiensi investasi modal pada tingkat perusahaan dan penentu utama produktivitas ekonomi perusahaan. Investasi dalam aset produktif melengkapi dan memperluas temuan tentang bagaimana akuntansi terkait dengan karakteristik pasar keuangan (Biddle et al., 2006).

Penelitian sebelumnya menunjukkan bahwa pelaporan keuangan berkualitas tinggi dapat meningkatkan efisiensi investasi dengan mengurangi asimetri informasi yang menyebabkan friksi ekonomi seperti moral hazard dan adverse selection (Leuz dan Verrecchia, 2000; Bushman dan Smith, 2001; Verrecchia, 2001). Cheng et al. (2013) menyatakan bahwa friksi yang bersumber dari kesenjangan informasi mengakibatkan investasi berjalan tidak efisien. Kualitas pelaporan keuangan yang lebih baik membuat manajer lebih bertanggung jawab dengan memungkinkan pemantauan yang lebih baik, dan dapat mengurangi asimetri informasi dan dapat mengurangi masalah over atau under investment (Gomariz dan Ballesta, 2014; Houcine, 2017)

Informasi laporan keuangan digunakan oleh pemegang saham untuk memonitor manajer (Bushman dan Smith, 2001; Lambert, 2001) dan merupakan sumber informasi spesifik perusahaan yang penting bagi investor (Bushman dan Indjejikian, 1993; Holmstrom dan Tirole, 1993; Kanodia dan Lee, 1998). Apabila pelaporan keuangan yang memiliki kualitas yang tinggi akan meningkatkan kemampuan pemegang saham untuk memantau aktivitas investasi manajerial, yang dapat dikaitkan dengan efisiensi investasi dengan mengurangi moral hazard.

Chang et al. (2009) mengusulkan adanya model adverse selection yang dinamis dan membuktikan secara empiris bahwa perusahaan dengan kualitas laporan keuangan yang lebih baik memiliki fleksibi- litas untuk mengeluarkan modal investasi. Apabila kualitas laporan keuangan menurunkan biaya adverse selection, maka hal tersebut dapat dikaitkan dengan efisiensi investasi melalui pengurangan biaya pendanaan eksternal dan kemungkinan perusahaan memperoleh dana yang lebih karena mispricing yang sifatnya temporer. Dengan demikian kualitas laporan keuangan dapat mengurangi terjadinya adverse selection.

Biddle et al. (2009) juga menyatakan bahwa ketika tingginya kualitas akuntansi dapat mengurangi asimetri informasi sehingga dapat meningkatkan efisiensi investasi. Biddle et al. (2009) dan Gomariz dan Ballesta (2014) menemukan laporan keuangan yang berkualitas menurunkan inefisiensi investasi yang bersumber dari under (over)investment.

Berdasarkan beberapa kajian teori dan hasil penelitian tersebut maka dapat dirumuskan hipotesis adanya pengaruh kualitas laporan keuangan terhadap efisiensi investasi melalui over atau underinvestment sebagai berikut:

$\mathrm{H}_{1 \mathrm{a}}$ : Kualitas laporan keuangan berpengaruh negatif terhadap over-investment.

$\mathrm{H}_{1 b}$ : Kualitas laporan keuangan berpengaruh negatif terhadap under-investment.

\section{Kualitas Laporan Keuangan, Pengendalian Internal dan Efisiensi Investasi}

Dampak terbitnya SOX di Amerika Serikat menyebabkan badan pengawas pasar modal Indonesia menerbitkan Peraturan Nomor VIII.G.11 (selanjut-nya disebut dengan Regulasi Bapepam-LK) pada tahun 2003 yang menetapkan bahwa sistem pengendalian internal perusahaan merupakan tanggung jawab direksi perusahaan dan harus dinyatakan secara tertulis di dalam laporan keuangan. Sebelum regulasi tersebut terbit, sistem pengawasan terhadap manajer perusahaan belum berjalan optimal. Hal ini dapat terlihat dari beberapa kasus praktik manajemen laba. Pengen- 
dalian internal yang lemah menciptakan peluang bagi manajer untuk mempengaruhi pelaporan keuangan dengan menampilkan angka-angka laporan keuangan yang tidak wajar.

Berdasarkan Keputusan Menteri $\mathrm{Ne}$ gara Badan Usaha Milik Negara Nomor: Per-01/MBU/2011 tentang Penerapan Tata Kelola Perusahaan Yang Baik (Good Corporate Governance pada BUMN pada Pasal 2 menyebutkan kewajiban BUMN menerapkan GCG, direksi menyusun GCG manual yang diantaranya memuat sistem pengendalian intern. Oleh pemerintah indikator pelaksanaan sistem pengendalian intern ini akan diperiksa dan diungkapkan melalui BPK melalui Ikhtisar Hasil Pemeriksaan Semester (IHPS) setiap tahun.

Pengendalian internal menjadi sangat penting untuk mengurangi kemungkinan terjadinya inefisiensi investasi. Arens et al. (2012) menyatakan pengendalian internal yang kuat dapat meningkatkan keandalan laporan keuangan. Konsisten dengan pandangan ini, Cheng et al. (2013) menemukan pengendalian internal berpengaruh positif terhadap efisiensi investasi. Ashbaugh-Skaife et al. (2008) memberikan bukti empiris bahwa perusahaan dengan pengungkapan pengendalian internal akan menunjukkan noise yang lebih besar pada akrual dan akrual abnormal yang lebih besar. Perusahaan dengan kelemahan pengendalian internal lebih cenderung memiliki kesalahan dalam hasil pelaporan keuangannya dan kualitas akuntansi yang lebih rendah. Pengendalian akuntansi internal yang lemah berarti rendahnya kualitas laba akuntansi. Dalam hal ini, pelaporan keuangan tidak dapat memainkan peran mengurangi adverse selection dan moral hazard yang timbul dari asimetri informasi antara perusahaan dan investor (Jaehong et al., 2016). Chalmers et al. (2018) menyatakan bahwa kualitas pengendalian internal mempengaruhi keputusan dan perilaku kreditur, investor, manajer, analis keuangan, auditor dan pemangku kepentingan lainnya.
Pengendalian internal yang efektif akan memberikan manfaat bagi para pihak internal dan eksternal perusahaan yang berkepentingan untuk mengurangi salah saji baik yang disengaja maupun yang disengaja terhadap informasi keuangan sehingga menyebabkan laporan keuangan menjadi lebih reliabel. Dengan demikian adanya pengendalian internal yang baik akan berdampak pada tingginya kualitas laporan keuangan perusahaan oleh manajer dan perusahaan dapat mengurangi asimetri informasi dan dapat menekan dilakukannya investasi dengan inefisien.

Berdasarkan beberapa kajian teori dan hasil penelitian tersebut maka hipotesis penelitian ini yaitu terdapat pengaruh kualitas laporan keuangan dan pengendalian internal terhadap efisiensi investasi melalui over atau under-investment sebagai berikut:

$\mathrm{H}_{2 \mathrm{a}}$ : Pengaruh kualitas laporan keuangan terhadap over-investment lebih kuat pada BUMN yang mengungkapkan pengendalian internalnya.

$\mathrm{H}_{2 \mathrm{~b}}$ : Pengaruh kualitas laporan keuangan terhadap under-investment lebih kuat pada BUMN yang mengungkapkan pengendalian internalnya.

\section{METODE PENELITIAN}

\section{Data dan Sampel Penelitian}

Penelitian dilakukan pada perusahaan BUMN di Indonesia baik yang listed dan non-listed (kecuali jasa keuangan dan asuransi) berbentuk perseroan terbatas (PT) dalam periode waktu tahun 2011-2016 sesuai hasil publikasi laporan keuangan yang telah diaudit dari Kementerian BUMN RI pada pada situs www.bumn.go.id. Data yang digunakan dalam penelitian ini bersumber dari ikhtisar laporan keuangan BUMN yang dipublikasikan pada website Kementerian BUMN (www.bumn.go.id), laporan tahunan masing-masing BUMN dan IHPS yang dikeluarkan oleh BPK RI. Penentuan sampel penelitian menggunakan purposive sampling dengan kriteria: pertama, BUMN terdaftar pada Kementerian BUMN 
RI dan BEI pada tahun pengamatan; kedua, memiliki data lengkap yang diperlukan dalam analisis data. Penelitian ini dilakukan pada 104 BUMN (208 firm years) berdasarkan data selama tahun 2011-2016. Analisis data adalah tahun 2015 dan 2016 sebagai konsekuensi perhitungan kualitas laporan keuagan menggunakan nilai standar deviasi $\mathrm{t}-1$ dan $\mathrm{t}-5$.

\section{Operasionalisasi dan Pengukuran Variabel Investasi}

Mengikuti Cheng et al. (2013), pengukuran investasi dilakukan dengan cara:

Investment $=[(R \mathcal{E D}+$ capital + acquisition expenditure) - (sale of PPE)]/lag total asset $\mathrm{x}$ 100

Investasi adalah total investasi yang diukur sebagai jumlah pengeluaran penelitian dan pengembangan, modal, dan akuisisi dikurangi penjualan property, plant, dan equipment dikalikan dengan 100 dan diskalakan oleh lag total asset

\section{Kualitas Laporan Keuangan}

Kualitas laporan keuangan (FRQ) diproksi dengan kualitas akrual dengan menggunakan model Stubben (2010):

$\Delta A R_{\mathrm{it}}=\mathrm{a}+\partial_{1} \Delta R 13_{\mathrm{it}}+\partial_{2} \Delta R 4_{\mathrm{it}}+\varepsilon 2 i t$

\section{Keterangan:}

Pertama, $\triangle A R$ adalah perubahan piutang perusahaan pada tahun fiskal sekarang dibandingkan dengan tahun sebelumnya.

Kedua, $\Delta R 1_{-} 3$ adalah perubahan pendapatan untuk tiga triwulan pertama (triwulan 1 sampai dengan 3) tahun fiskal sekarang dibandingkan dengan tahun fiskal sebelumnya.

Ketiga, $\triangle A R 4$ adalah perubahan pendapatan untuk triwulan ke empat pada tahun fiskal sekarang dibandingkan dengan tahun sebelumnya.

Keempat, FRQ merupakan standar deviasi dari residual pada setiap per- usahaan dari model tersebut yang dihitung dari persamaan (5) dari tahun $\mathrm{t}-5$ sampai dengan $\mathrm{t}-1$. Berdasarkan perhitungan standar deviasi dengan menggunakan data 5 tahun untuk memperoleh nilai residual di masing-masing tahun, maka standar deviasi sebagai kualitas akrual yang menjadi proksi FRQ yang akan dianalisis adalah tahun 2015 (residual 2011 s/d 2015) dan 2016 (residual $2012 \mathrm{~s} / \mathrm{d} 2016$ ).

\section{Pengendalian Internal}

Variabel Pengendalian Internal (Internal Control/IC) adalah pengendalian internal, menggunakan proksi hasil pemeriksaan IHPS oleh BPK, dengan menggunakan dummy yaitu: kategori: "sesuai dengan kriteria yang telah ditetapkan" $=3$, "sesuai dengan pengecualian atas kriteria yang ditetapkan" = 2 dan "tidak sesuai dengan kriteria yang ditetapkan" $=1$

\section{Over/under-investment}

Over/under-investment diukur seperti pada penelitian Cheng et al. (2013). Prosedur yang digunakan adalah: pertama, menentukan saldo kas (tinggi) dan utang perusahan (rendah) yang cenderung melakukan overinvestment dan sebaliknya untuk underinvestment. Kedua, melakukan ranking saldo kas dan utang yang negatif pada akhir tahun t-1 menjadi dua jajaran desil. Ketiga, merata-ratakan dua peringkat desil tersebut dan diskala sehingga terdapat kisaran 0 sampai dengan 1. Keempat, melakukan transformasi ranking desil dengan rumus: (Nilai desil - 1): 9

\section{Listed dan Non-Listed}

Variabel Listed dan Non-Listed menggunakan dummy, yaitu: $1=$ Listed; $0=$ NonListed.

\section{Variabel Kontrol}

Variabel kontrol berdasarkan asumsi determinan pengendalian internal dan tingkat investasi seperti pada penelitian Cheng et al. (2013), yaitu: 
Pertama, Determinan pengendalian internal seperti pada Cheng et al. (2013): Size $=\log$ total aset; $A g e=\log$ umur perusahaan

Kedua, Determinan tingkat investasi seperti pada Cheng et al. (2013) yaitu Loss = rugi yaitu variabel dummy, 1 = laba negatif; 0 = lainnya

\section{Teknik Pengujian Hipotesis Model Penelitian}

a. Model yang digunakan untuk menguji pengaruh kualitas laporan keuangan terhadap over atau under-investment (H1a dan $\mathrm{H} 1 \mathrm{~b}$ ) diadopsi dari model penelitian Biddle et al. (2009) sebagai berikut:

Investment $_{i, t+1}=\alpha+\beta_{1}$ FRQ $_{i, t}+\beta_{2} \mathrm{Ov} /$ UndInv $_{\mathrm{t}}+\beta_{3} \mathrm{FRQ}_{\mathrm{i}, \mathrm{t}}{ }^{*} \mathrm{Ov} / \mathrm{UndInv}_{\mathrm{i}, \mathrm{t}}+\beta_{4}$ Size $_{\mathrm{i}, \mathrm{t}}+\beta_{5}$ Age $_{\mathrm{i}, \mathrm{t}}+\beta_{6}$ Loss $_{\mathrm{i}, \mathrm{t}}+\varepsilon_{\mathrm{i}, \mathrm{t}} \ldots \ldots \ldots$ (1)

b. Model yang digunakan untuk menguji pengaruh kualitas laporan keuangan dan pengendalian internal terhadap over atau under-investment $(\mathrm{H} 2 \mathrm{a}$ dan $\mathrm{H} 2 \mathrm{~b})$ diadopsi dari penelitian Cheng et al. (2013) sebagai berikut:

Investment $_{\mathrm{i}, t+1}=a+\beta_{1} \mathrm{FRQ}_{\mathrm{i}, \mathrm{t}}+\beta_{3} \mathrm{Ov} /$ UndInv $_{\mathrm{t}}+\beta_{2} \mathrm{FRQ}_{\mathrm{i}, \mathrm{t}}{ }^{*} \mathrm{Ov} /$ UndInv $_{\mathrm{i}, \mathrm{t}}+$ $\beta_{4} \mathrm{IC}_{\mathrm{i}, \mathrm{t}}+\beta_{5} \mathrm{FRQ}_{\mathrm{i}, \mathrm{t}}{ }^{*} \mathrm{IC}_{\mathrm{i}, \mathrm{t}}+\beta_{6} \mathrm{FRQ}_{\mathrm{it}}{ }^{*} \mathrm{Ov} /$ UndInv $_{\text {it }}{ }^{*} \mathrm{IC}_{\mathrm{it}}+\beta_{7} \mathrm{Size}_{\mathrm{i}, \mathrm{t}}+\beta_{8} \mathrm{Age}_{\mathrm{i}, \mathrm{t}}+$ $\beta_{9} \operatorname{Loss}_{\mathrm{i}, \mathrm{t}}+\varepsilon_{\mathrm{i}, \mathrm{t}}$

\section{Pengujian Hipotesis}

Pertama, analisis statistik deskriptif bertujuan untuk memberikan gambaran umum mengenai observasi penelitian dengan melihat nilai minimum, nilai maksimun, nilai rata-rata (mean) dan nilai standar deviasi dari setiap variabel yang digunakan dalam model penelitian.

Kedua, analisis data dilakukan dengan menggunakan persamaan regresi linier yang diolah dengan program SPSS versi 21. Sebelumnya dilakukan uji asumsi klasik meliputi: uji multikolinieritas dengan melakukan perhitungan nilai tolerance dan Variance Inflation Factor (VIF), uji autokorelasi menggunakan uji Durbin-Watson, uji heterokedastisitas pada persamaan (1) dan (2) menggunakan uji Glejser (Ghozali, 2012). Pengujian hipotesis penelitian berdasarkan persamaan regresi (1) dan (2) dengan tingkat signifikansi $(\alpha)=0,05$. Jika nilai signifikansi $<0,05$ maka disimpulkan hipotesis tidak dapat ditolak.

\section{ANALISIS DAN PEMBAHASAN Deskripsi Sampel}

Penelitian ini dilakukan pada 104 BUMN (208 firm years) berdasarkan data yang tersedia sesuai kebutuhan penelitian yaitu selama tahun 2011-2016. Analisis data adalah tahun 2015 dan 2016 sebagai konsekuensi perhitungan kualitas laporan keuagan menggunakan nilai standar deviasi t-1 dan t-5. BUMN yang dijadikan sampel pada penelitian ini tersebar pada 27 sektor dengan rincian sektor BUMN seperti pada Tabel 1 berikut.

Tabel 1

Rincian Sampel Per Sektor

\begin{tabular}{lcc}
\hline \hline \multicolumn{1}{c}{ Sektor BUMN } & Jumlah & $\mathbf{( \% )}$ \\
\hline Perkebunan & 16 & 15,38 \\
Kehutanan & 5 & 4,8 \\
Perikanan & 1 & 0.9 \\
Penunjang Pertanian & 2 & 1,9 \\
Pupuk & 1 & 0,9 \\
Pertambangan & 4 & 3,8 \\
Energi & 4 & 3,8 \\
Semen & 3 & 2,8 \\
Pertahanan & 4 & 3,8 \\
Baja, Manufaktur \& Rekayasa & 4 & 3,8
\end{tabular}


Lanjutan Tabel 1

\begin{tabular}{lcc} 
Dok \& Perkapalan & 2 & 1,9 \\
Farmasi & 3 & 2,8 \\
Telekomunikasi \& Media & 3 & 2,8 \\
Aneka Industri & 4 & 3,8 \\
Konstruksi & 9 & 8,6 \\
Kertas \& Percetakan & 3 & 2,8 \\
Listrik & 1 & 0,9 \\
Pelabuhan & 4 & 3,8 \\
Bandar Udara & 2 & 1,9 \\
Angkutan Darat/Laut/Udara & 5 & 4,8 \\
Konsultan Konstruksi & 5 & 4,8 \\
Kawasan Industri & 4 & 3,8 \\
Pergudangan & 2 & 1,9 \\
Perdagangan & 2 & 1,9 \\
Sertifikasi & 3 & 2,8 \\
Perhotelan \& Pariwisata & 2 & 1,9 \\
Lain-Lain & 6 & 5,7 \\
\hline Total & $\mathbf{1 0 4}$ & $\mathbf{1 0 0}$
\end{tabular}

Sumber: data penelitian (diolah), 2017.

\section{Statistik Deskriptif}

Hasil pengujian statistik deskriptif berdasarkan nilai mean dan standar deviasi pada data penelitian disajikan dalam Tabel 2. Berdasarkan statistik deskriptif dapat dijelaskan bahwa untuk investasi berada pada rata-rata 5,3276 artinya bahwa investasi pada BUMN pada rentang tahun pengamatan dilakukan sebesar rata-rata $5,32 \%$ dari total aset yang dimiliki oleh perusahaan. Kualitas laporan keuangan berdasarkan kualitas akrual rata-rata sebesar 0,4312 yang dihitung berdasarkan perhitungan standar deviasi nilai residual selama 5 tahun dari nilai piutang usaha dan pendapatan perusahaan.

Dilihat dari Over/UnderInvestment pada data sampel menujukkan bahwa ranking desil dari hasil transformasi yang dilakukan dari nilai kas dan utang perusahaan berada pada rata-rata 0,06 artinya perusahaan lebih cenderung melakukan underinvestment dibandingkan overinvestment karena nilai lebih mendekati nilai 0 . Hal tersebut kemungkinan sebagai konsekuensi kecilnya nilai investasi yang dilakukan perusahaan dan laba yang diperoleh perusahaan. Berdasarkan atas pengungkapan pengendalian internal perusahaan dari hasil pemeriksaaan BPK RI menunjukkan bahwa rata-rata nilai mendekati 2. Hal ini berarti bahwa perusahaan belum sepenuhnya menjalankan pengendalian internal (SPI) dengan baik karena beberapa ketidak patuhan dengan predikat sesuai dengan pengecualian atas kriteria yang telah ditetapkan. Dilihat dari nilai total aset yang dimiliki dengan trasformasi logaritma nilai aset perusahaan menunjukkan rata-rata aset perusahaan sebesar 4 trilyun rupiah.

Berdasarkan umur perusahaan menunjukkan rata-rata 1,518 yang merupakan nilai log umur perusahaan yang apabila ditransformasikan ke angka tahun, maka rata-rata umur perusahaan adalah 25 tahun. Dilihat dari rata-rata loss perusahan menunjukkan hasil bahwa mayoritas perusahaan memiliki laba positif dibandingkan laba negatif.

\section{Uji Asumsi Klasik}

\section{Uji Multikolinearitas}

Tabel 3 menunjukkan hasil pengujian multikolinieritas berdasarkan nilai tolerance tidak ada yang $\leq 0,10$ dan nilai VIF tidak ada yang $\geq 10$, sehingga dapat disimpulkan 
bahwa tidak terjadi multikolinieritas pada persamaan regresi 1 dan 2.

\section{Uji Autokorelasi}

Hasil pengujian autokorelasi pada persamaan (1) dan (2) berdasarkan nilai Durbin-Watson (untable) menunjukkan nilai $\mathrm{d}=2,043$. Pada persamaan (1) dengan jumlah variabel bebas $(k)=6$ dan $n=208$, nilai $\mathrm{dL}=1,707 ; \mathrm{dU}=1,831$ keputusan tidak ada autokorelasi pada persamaan karena $\mathrm{dU}<\mathrm{d}<4$-dU.

Pada persamaan (2) dengan jumlah varabel bebas $(k)=7$ dan $n=208$, nilai $d L=$ 1,603; nilai $\mathrm{dU}=1,746$ keputusan tidak ada autokorelasi pada persamaan karena $\mathrm{dU}<\mathrm{d}<4-\mathrm{dU}$.

Tabel 2

Statistik Deskriptif

\begin{tabular}{lrc}
\hline \hline \multicolumn{1}{c}{ Variabel } & Mean & Standar Deviasi \\
\hline Investasi & 5,3276 & 2,2631 \\
FRQ & 0,4312 & 0,2093 \\
Over/UnderInv & 0,06 & 0,0903 \\
Pengendalian Internal (IC) & 1,9971 & 0,4887 \\
Total Aset (log) & 12,7632 & 0,8167 \\
Age (log) & 1,518 & 0,3176 \\
Loss & 0,0982 & 0,3108 \\
Sampel & 208 & 208 \\
\hline
\end{tabular}

Keterangan: Tabel ini mempresentasikan hasil uji statistik deskrptif. Variabel independen yaitu Investasi diukur dengan penjumlahan $R \mathcal{E} D$, capital, acquitiuion expenditure dan PPE dibagi total aset dibagi 100, variabel independen yaitu kualitas laporan keuangan (FRQ) yang dihitung dengan model Stubben, Over/UnderInvestment dihitung dengan melakukan ranking desil dan transformasi desil dari jumlah kas dan jumlah utang, pengendalian internal sebagai pemoderasi dihitung berdasarkan kriteria BPK RI yaitu "sesuai dengan kriteria yang telah ditetapkan" $=3$, "sesuai dengan pengecualian atas kriteria yang ditetapkan" = 2 dan "tidak sesuai dengan kriteria yang ditetapkan" $=1$, Size $=\log$ total aset, Age = umur perusahaan dengan menghitung log umur perusahaan, Loss $=$ rugi yaitu 1 = laba negatif dan $0=$ lainnya.

Sumber: data diolah, 2017.

Tabel 3

Hasil Uji Multikolinieritas

\begin{tabular}{lcccc}
\hline \multirow{2}{*}{ Variabel } & \multicolumn{2}{c}{ Model 1 } & \multicolumn{2}{c}{ Model 2 } \\
\cline { 2 - 5 } & Tolerance & VIF & Tolerance & VIF \\
\hline FRQ & 0,163 & 6,471 & 0,163 & 6,471 \\
OverUnder & 0,962 & 1,053 & 0,961 & 1,052 \\
LogTA & 0,973 & 1,050 & 0,971 & 1,051 \\
Age & 0,990 & 1,021 & 0,988 & 1,023 \\
Loss & 0,999 & 1,001 & 0,979 & 1,021 \\
IC & - & - & 0,978 & 1,025 \\
\hline
\end{tabular}

Sumber: data diolah, 2017. 


\section{Uji Heterokedastisitas}

Pengujian heterokedastisitas pada persamaan (1) dan (2) menggunakan uji Glejser SPSS dengan cara mencari nilai residual setiap persamaan dan mengabsolutkan nilai residual tersebut diperoleh hasil. Hasil pengujian menunjukkan bahwa tidak terdapat variabel independen dalam persamaan yang nilai signifikansinya dibawah 0,05 . Artinya persamaan (1) dan (2) terbebas dari deteksi heterokedastisitas.
Pengujian Hipotesis

Kualitas laporan keuangan berpengaruh negatif terhadap over/under-investment.

Hasil Regresi

Tabel 4 menunjukkan hasil regresi persamaan (1) untuk menjawab hipotesis 1a dan $1 b$ pada penelitian yaitu kualitas laporan keuangan berpengaruh negatif terhadap over/under-investment dengan persamaan regresi menggunakan SPSS.

Tabel 4

Hasil Uji Regresi Hipotesis 1a dan 1 b

\begin{tabular}{lccc}
\hline \hline & Ekspektasi Tanda & Koefisien & Signifikansi \\
\hline FRQ & + & 2.875 & $0.038^{* *}$ \\
Over/UnderInv & - & -.028 & 0.443 \\
FRQ*Over/Under & - & -3.811 & $0.030^{* *}$ \\
LogTotal Aset & - & -0.520 & $0.047^{* *}$ \\
LogAge & - & 0.014 & 0.634 \\
Loss & - & -0.005 & 0.871 \\
Intercept & $?$ & 7.384 & $0.026^{* *}$ \\
Adjusted R-square & & & 0.216 \\
N & & & 208 \\
\hline$* *$ Signifikan pada & & \\
\hline
\end{tabular}

**Signifikan pada level 5\%

Keterangan: Tabel ini mempresentasikan estimasi persamaan 1 untuk pengujian hipotesis $1 \mathrm{a}$ dan $1 \mathrm{~b}$ pada penelitian untuk menganalisis pengaruh kualitas laporan keuangan terhadap over/under investment. Variabel independen yaitu Investasi diukur dengan penjumlahan $R \mathcal{E} D$, capital, acquitiuion expenditure dan PPE dibagi total aset dibagi 100, variabel independen yaitu kualitas laporan keuangan (FRQ) yang dihitung dengan model Stubben, Over/UnderInvestment dihitung dengan melakukan ranking desil dan transformasi desil dari jumlah kas dan jumlah utang, Size $=\log$ total aset, Age = umur perusahaan dengan menghitung log umur perusahaan, Loss = rugi yaitu 1 = laba negatif dan $0=$ lainnya.

Sumber: data diolah, 2017.

\section{Pembahasan}

Berdasarkan hasil pengujian hipotesis $1 \mathrm{a}$ dan $1 \mathrm{~b}$ seperti yang ditampilkan pada tabel 4 menunjukkan bahwa dengan adanya kualitas laporan keuangan yang dilakukan oleh perusahaan akan berpengaruh negatif baik bagi over maupun under-investment. Hal ini ditunjukkan dengan nilai $\beta_{1}$ dan $\beta_{3}$ sesuai ekspektasi penelitian ini. Berdasarkan perankingan nilai desil dan transformasi nilai investasi dari over ke under dalam analisis berhasil membuktikan bahwa hal tersebut mendukung hipotesis $1 \mathrm{a}$ dan $1 \mathrm{~b}$ dalam penelitian ini. Bagi perusahaan dalam hal ini BUMN yang mayoritas modalnya dimiliki oleh negara melalui penyertaan modal secara langsung yang berasal dari kekayaan negara dan sangat higly regulated dengan kepatuhannya melakukan rangkaian investasi sesuai regulasi yang mengaturnya dan dalam pengawasan pemerintah serta sistem kerja manajemen 
perusahaan yang ketat. Penggunaan aset BUMN dalam melakukan investasi juga turut mempengaruhi keputusan investasi perusahaan karena sebagai bentuk pertanggungjawaban penggunaan modal kepada pemilik (pemerintah). Hal ini ditunjukkan dengan bahwa variabel log total aset sebagai proksi aset BUMN adalah negatif signifikan dalam persamaan regresi mempengaruhi investasi perusahaan (over) under-investment). Akan tetapi berdasarkan variabel Age (umur perusahaan) dan Loss tidak mempengaruhi investasi perusahaan dalam persamaan regresi.

Analisis berdasarkan teori agensi dari hasil penelitian tersebut menunjukkan bahwa hubungan prinsipal dan agen sangat mempengaruhi tata kelola BUMN dalam melakukan putusan investasi melalui kualitas laporan keuangan. Pengawasan pemerintah terhadap manajemen perusahaan menunjukkan telah dilaksanakannya ketentuan dalam Undang-Undang Nomor 19 Tahun 2003 tentang BUMN yang pada dasarnya hubungan keagenan antara BUMN dan Pemerintah tampak jelas pada hubungan pemerintah dengan dewan komisaris, pemerintah dengan dewan direksi dan hubungan dewan komisaris dan dewan direksi.

Ketiga hubungan tersebut akan berdampak pada tata kelola BUMN secara keseluruhan khususnya terkait dengan pengelolaan aset negara oleh BUMN dalam bentuk investasi bagi kesejahteraan masyarakat. Hasil penelitian ini sejalan dengan temuan Chang et al. (2009), Biddle et al. (2009) serta Gomariz dan Ballesta (2014) dengan sampel yang berbeda.

Pengaruh kualitas laporan keuangan terhadap over/under-investment lebih kuat pada BUMN yang mengungkapkan pengendalian internalnya.

\section{Hasil Regresi}

Pada Tabel 5 menunjukkan hasil regresi persamaan 2 untuk menjawab hipotesis $2 \mathrm{a}$ dan $2 b$ pada penelitian yaitu pengaruh kualitas laporan keuangan terhadap over/ under-investment lebih kuat pada BUMN yang mengungkapkan pengendalian internalnya dengan persamaan regresi menggunakan analisis SPSS.

\section{Pembahasan}

Berdasarkan hasil pengujian hipotesis $2 \mathrm{a}$ dan $2 \mathrm{~b}$ seperti yang ditampilkan pada Tabel 5 menunjukkan bahwa pengaruh kualitas laporan keuangan terhadap over/ under-investment lebih kuat pada BUMN yang mengungkapkan pengendalian internalnya $\mathrm{Hal}$ ini ditunjukkan dengan nilai $\beta 1$, $\beta_{5}$ dan $\beta_{6}$ sesuai ekspektasi penelitian ini. Dengan demikian hasil pengujian mendukung hipotesis $2 \mathrm{a}$ dan $2 \mathrm{~b}$ bahwa adanya kualitas laporan keuangan dan pengendalian internal akan berpengaruh negatif pada over/under-investment, dengan kata lain adanya pengendalian internal memperkuat pengaruh kualitas laporan keuangan terhadap over/under-investment. Serupa dengan analisis pada hipotesis $1 \mathrm{a}$ dan $1 \mathrm{~b}$ untuk variabel kontrol yaitu penggunaan aset BUMN dalam melakukan investasi juga turut mempengaruhi keputusan investasi perusahaan karena sebagai bentuk pertanggungjawaban penggunaan modal kepada pemilik (pemerintah). Hal ini ditunjukkan dengan bahwa variabel $\log$ total aset sebagai proksi aset BUMN adalah negatif signifikan dalam persamaan regresi mempengaruhi investasi perusahaan (over/ under-investment). Hal yang berbeda bahwa variabel Age (umur perusahaan) dan Loss tidak mempengaruhi investasi perusahaan dalam persamaan regresi.

Dasar pengujian hipotesis tentang peran pengendalian internal karena BUMN memiliki peran mengelola aset negara dan risiko usaha dalam setiap pengambilan keputusan karena perubahan lingkungan bisnis. Oleh karena itu BUMN wajib merancang dan menerapkan Sistem Pengendalian Intern (SPI) yang efektif dalam mengelola risiko secara terpadu sebagai bagian dari pelaksanaan tata kelola per usahaan. Hal itu telah diatur sedemikian rupa dalam ketentuan peraturan per- 
undang-undangan tentang BUMN (UU Nomor 19 Tahun 2003) yang pelaksanaannya diserahkan kepada Badan Pemeriksa Keuangan (BPK) RI sebagai auditor yang akan melakukan penilaian terhadap efektivitas pelaksanaan SPI dan kepatuhan pada ketentuan perundang-undangan.
Pengelolaan pengendalian internal yang baik akan mempengaruhi bagaimana suatu organisasi dikelola (corporate governance), sedangkan corporate governance sendiri dipengaruhi oleh adanya dukungan dari pengendalian intern yang baik.

Tabel 5

Hasil Uji Regresi Hipotesis 2a dan 2b

\begin{tabular}{lccc}
\hline \hline & Ekspektasi Tanda & Koefisien & Signifikansi \\
\hline FRQ & + & 2.961 & $0.040^{* *}$ \\
Over/UnderInv & - & -0.070 & 0.442 \\
FRQ*OverUnderI & - & -3.726 & $0.031^{* *}$ \\
IC & - & -0.21 & 0.966 \\
FRQ*IC & - & -2.050 & $0.036^{* *}$ \\
FRQ ${ }^{*}$ OvUnI*IC & + & 4.788 & $0.044^{* *}$ \\
Log Total Aset & - & -0.530 & $0.047^{* *}$ \\
Log Age & - & 0.014 & 0.634 \\
Loss & - & -0.005 & 0.871 \\
Constanta & $?$ & 7.991 & $0.036^{* *}$ \\
Adjusted R-square & & & 0.232 \\
$\mathrm{~N}$ & & & 208 \\
\hline **Signifikan pada level 5\% & &
\end{tabular}

Keterangan: Tabel ini mempresentasikan estimasi persamaan 2 untuk pengujian hipotesis $2 \mathrm{a}$ dan $2 \mathrm{~b}$ pada penelitian untuk menganalisis pengaruh kualitas laporan keuangan terhadap over/under-investment lebih kuat pada BUMN yang mengungkapkan pengendalian internalnya. Variabel independen yaitu Investasi diukur dengan penjumlahan $R \mathcal{E} D$, capital, acquitiuion expenditure dan PPE dibagi total aset dibagi 100, variabel independen yaitu kualitas laporan keuangan (FRQ) yang dihitung dengan model Stubben, Over/UnderInvestment dihitung dengan melakukan ranking desil dan transformasi desil dari jumlah kas dan jumlah utang, pengendalian internal sebagai pemoderasi dihitung berdasarkan kriteria BPK RI yaitu "sesuai dengan kriteria yang telah ditetapkan" $=3$, "sesuai dengan pengecualian atas kriteria yang ditetapkan" = 2 dan "tidak sesuai dengan kriteria yang ditetapkan" = 1, Size = log total aset, Age = umur perusahaan dengan menghitung log umur perusahaan, Loss = rugi yaitu 1 = laba negatif dan $0=$ lainnya.

Sumber: data diolah, 2017.

Kecenderungan terjadinya fraud menyebabkan pengendalian internal menjadi salah satu fokus utama pada perusahaan. Pengungkapan atau disclosure atas pengendalian intern menjadi point penting bagi penilaian perusahaan dan seringkali menjadi faktor penentu dalam pengambilan keputusan terlebih dalam melakukan investasi. Jensen dan Meckling (1976) menyata- kan bahwa hubungan keagenan antara prinsipal dan agen merupakan asosiasi pemisahan kepemilikan dan pengendalian. Fungsi pengendalian internal dalam kaitannya antara pemerintah dan BUMN merupakan antisipasi terhadap penyimpangan potensial atas perilaku kooperatif keduanya sehingga dapat menghindari minimisasi terhadap tindakan maksimisasi kemakmur- 
an kelompok atau individu. Hal tersebut menjadi urgen karena terdapat delegasi tanggung jawab aset negara kepada BUMN sebagai pihak pengelola aset tersebut untuk digunakan dalam rangka meningkatkan kesejahteraan masyarakat, sehingga diperlukan pengendalian internal secara efektif.

Adanya pengendalian internal yang baik dalam konteks penelitian ini adalah adanya dampak pada kualitas laporan keuangan pada BUMN sehingga mempengaruhi keputusan investasi perusahaan. Hasil penelitian ini sejalan dengan penelitian yang dilakukan oleh AshbaughSkaife et al. (2008), Arens et al. (2012) dan Cheng et al. (2013).

\section{Pengujian Tambahan BUMN Listed dan Non-Listed}

Seperti diketahui bahwa perusahaan yang listed di pasar bursa memiliki konsekuensi yang highly regulated selain dari pemerintah juga peraturan pasar modal dalam hal ini di Indonesia adalah Bursa Efek Indonesia. Hal tersebut menyebabkan perusahaan yang listed cenderung memiliki ketaatan dalam publikasi pelaporan keuangan yang berguna bagi investor dan pihak lain yang berkepentingan. Hal tersebut tidak berlaku dan kewajiban bagi perusahaan yang non-listed karena hanya patuh pada regulasi oleh pemerintah saja.

BUMN sebagai perusahaan yang sebagian besar modalnya dimiliki pemerintah dari kekayaan negara yang dipisahkan, selain patuh terhadap regulasi pemerintah, maka bagi BUMN yang listed akan memiliki konsekuensi kewajiban yang sama dengan perusahaan yang listed di bursa efek dibandingkan dengan BUMN yang nonlisted. Hal tersebut akan cenderung berindikasi pada kegiatan investasi perusahaan yang berbeda antara BUMN yang listed dengan non-listed. Selain itu, sebagai pembuktian adanya teori agensi pada hubungan pemerintah dan BUMN, pengujian ini dilakukan untuk menganalisis keberadaan BUMN yang higly regulated antara yang listed dan non listed. Berdasarkan hal tersebut sebagai pembuktian secara empirisnya, maka diasumsikan bahwa pengaruh kualitas laporan keuangan terhadap over/ under-investment lebih kuat pada BUMN yang listed dibandingkan BUMN non-listed. Pengujian dilakukan dengan mengambil sampel BUMN non-listed sebanyak sampel BUMN listed, dikarenakan pertimbangan jumlah sampel BUMN non-listed lebih banyak dibandingkan BUMN listed dengan melakukan perankingan nilai over/underinvestment tertinggi dan terendah.

Jumlah sampel BUMN listed adalah 30 firm-years. Ranking nilai over-investment diambil dari ranking teratas 1 sampai dengan 7 , sedangkan nilai under-investment diambil dari rangking terbawah 1 sampai dengan 8 , sehingga jumlah sampel BUMN listed dan non-listed sama-sama sebanyak 30 firm-years. Hal ini dilakukan untuk mengatasi ketimpangan jumlah sampel mengingat digunakannya variabel dummy untuk proksi BUMN listed dan non-listed serta mengatasi terjadinya multikolonieritas.

Model yang digunakan untuk menguji pengaruh kualitas laporan keuangan dan pengendalian internal terhadap over atau under-investment akan lebih baik pada BUMN listed dibandingkan non-listed sebagai berikut:

Investment $_{i, t+1}=\alpha+\beta_{1}$ FRQ $_{i, t}+$ $\beta_{2}$ Over/UnderI $I_{t}+\beta_{3} F_{R Q} Q_{i, t}{ }^{*}$ Over/UnderI $I_{i, t}+$ $\beta_{4}$ Listed/Non-Listed $+\beta_{5} \mathrm{FRQ}_{\mathrm{it}}{ }^{*}$ Over/ UnderI ${ }^{*}$ Listed/Non-Listed $+\beta_{6}$ Size $_{i, t}+$

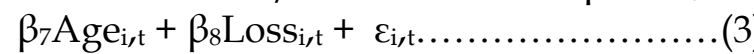

Pengujian persamaan (3) dilakukan dengan membuat variabel BUMN listed dan non-listed dengan menggunakan dummy yaitu 1 untuk BUMN listed dan 0 untuk BUMN non-listed. Hasil pengujian persamaan tersebut ditampilkan pada Tabel 6. Berdasarkan pengujian pada Tabel 6 menunjukkan bahwa status perusahaan sebagai BUMN yang listed dan non-listed sangat mempengaruhi adanya kualitas laporan keuangan dan keputusan investasi pada perusahaan. BUMN yang highly 
regulated akan lebih diperketat dengan regulasi dari bursa efek dalam setiap aktivitas bisnis di pasar modal yang berhubungan lebih dekat dengan pihak investor dan mekanisme pasar, khususnya bagi BUMN yang listed. Hal tersebut didukung oleh hasil pengujian tambahan ini dengan melihat nilai $\beta_{1}$ dan $\beta_{5}$ dengan signifikan lebih kecil dari 0,05 serta nilai $R$ square yang lebih tinggi dari 2 (dua) pengujian sebelumnya yaitu sebesar 0,509 .

Dengan demikian dugaan pengujian tambahan ini sehubungan dengan status
BUMN listed dan non listed dapat dibuktikan meskipun hanya menganalisis dari aspek kegiatan investasi perusahaan saja. Seperti yang telah dikemukakan sebelumnya bahwa selain higly regulated, BUMN listed juga harus mengikuti regulasi pasar modal (BEI) dan mekanisme pasar yang berhubungan dengan investor dan pihak luar lainnya yang berkepentingan dengan operasional (kinerja) BUMN. Hal tersebut juga sekaligus menjawab makin ketatnya hubungan keagenan antara pemerintah dan BUMN listed dalam penelitian ini.

Tabel 6

Hasil Pengujian Tambahan BUMN Listed dan Non-Listed

\begin{tabular}{lccc}
\hline \hline & Ekspektasi Tanda & Koefisien & Signifikansi \\
\hline FRQ & + & 2.980 & $0.039^{* *}$ \\
Over/UnderInv & - & -0.035 & 0.441 \\
FRQ*OverUnderI & - & -3.730 & $0.030^{* *}$ \\
Listed/NListed & $?$ & 0.29 & 0.417 \\
FRQ*OvUnI*List & - & -0.111 & $0.000^{* *}$ \\
Log Total Aset & - & -0.521 & $0.047^{* *}$ \\
Log Age & - & 0.012 & 0.630 \\
Loss & - & -0.004 & 0,867 \\
Constanta & $?$ & 7.775 & $0.028^{* *}$ \\
Adjusted R-square & & & 0.508 \\
N & & & 208 \\
\hline$* *$ Signifikan pada level 5\% & & &
\end{tabular}

**Signifikan pada level 5\%

Keterangan: Tabel ini mempresentasikan estimasi persamaan 3 untuk pengujian tambahan pada penelitian untuk menganalisis pengaruh kualitas laporan keuangan terhadap over/under-investment lebih kuat pada BUMN yang listed dibandingkan BUMN non-listed. Variabel independen yaitu Investasi diukur dengan penjumlahan RED, capital, acquitiuion expenditure dan PPE dibagi total aset dibagi 100, variabel independen yaitu kualitas laporan keuangan (FRQ) yang dihitung dengan model Stubben, Over/UnderInvestment dihitung dengan melakukan ranking desil dan transformasi desil dari jumlah kas dan jumlah utang, Listed/Non-Listed diukur dengan dummy $1=$ listed dan $0=$ non-listed, Size $=\log$ total aset, Age $=$ umur perusahaan dengan menghitung log umur perusahaan, Loss = rugi yaitu $1=$ laba negatif dan $0=$ lainnya.

Sumber: data diolah, 2017.

\section{SIMPULAN DAN SARAN \\ Simpulan}

Penelitian ini bertujuan untuk menganalisis hubungan kualitas laporan keuangan dan over/under-investment serta adanya pengaruh kualitas laporan keuangan terhadap over/under-investment dengan ada- nya pengungkapan tingkat pengendalian internal pada perusahaan BUMN yang listed dan non listed di Indonesia. Hasil penelitian menunjukkan dukungan hipotesis penelitian ini yaitu bahwa kualitas laporan keuangan berpengaruh negatif terhadap over/ under-investment dan pengaruh kualitas 
laporan keuangan terhadap over/underinvestment lebih kuat pada BUMN yang mengungkapkan pengendalian internalnya.

Untuk memperkuat hasil penelitian dilakukan pengujian tambahan. Hasilnya menunjukkan bahwa BUMN listed lebih memiliki kekuatan penjelas pada pengaruh kualitas laporan keuangan terhadap over/ under-investment dibandingkan BUMN nonlisted.

\section{Keterbatasan Penelitian}

Meskipun hipotesis dalam penelitian ini terdukung dari hasil pengujian, beberapa keterbatasan dalam penelitian ini perlu dikemukakan agar interpretasi hasil penelitian dilakukan secara hati-hati dengan mempertimbangkan segala keterbatasan yang ada. Selain itu, keterbatasan penelitian berguna bagi pengembangan penelitian sejenis dimasa depan. Adapun keterbatasan dalam penelitian ini sebagai berikut: pertama, minimnya jumlah perusahaan yang dijadikan sampel dikarenakan data annual report yang dipublikasikan oleh Kementerian BUMN dan hasil pemeriksaan oleh BPK RI. Kesulitan mengakses data lengkap dari web BUMN disertai dengan menelusuri web masing-masing BUMN menjadi faktor kesulitan dalam mentabulasi data. Kedua, berdasarkan point 1, menjadi keterbatasan penggunaan variabel kontrol dalam model/persamaan regresi pada penelitian. Ketiga, periode penelitian hanya 2 (dua) tahun yaitu 2015-2016 sebagai efek point 1 dan perhitungan standar deviasi dalam menentukan nilai over/underinvestment pada penelitian ini. Keempat, tidak dilakukan analisis sensitivitas karena keterbatasan data annual report BUMN yang dipublikasikan.

\section{Saran}

Berdasarkan simpulan dan keterbatasan penelitian tersebut, maka bagi penelitian selanjutnya untuk melakukan pertimbangan penggunaan sampel penelitian BUMN dengan menelusuri karaktristik yang dapat dianalisis dalam model penelitian, peng- gunaan variabel kontrol dan pengembangan pengukuran variabel penelitian yang berhubungan dengan kualitas laporan keuangan dan efisiensi investasi. Bagi regulator yaitu sebagai bahan masukan dalam membuat kebijakan selanjutnya terkait dengan kualitas laporan keuangan dan efisiensi investasi. Bagi perusahaan bahwa hasil penelitian ini dapat digunakan sebagai bahan pertimbangan dalam melakukan pengelolaan operasional dan efektifitas pendanaan perusahaan dan pelaksanaan sistem pengendalian intern yang memadai khususnya terhadap pentingnya kualitas laporan keuangan dan aktivitas investasi melalui aset negara yang dimiliki perusahaan sehingga berdampak terhadap tata kelola perusahaan untuk meningkatkan kepercayaan investor dan keuntungan bagi perusahaan (negara) dan masyarakat di masa yang akan datang.

\section{DAFTAR PUSTAKA}

Altamuro, J. dan A. Beatty. 2010. How does Internal Control Regulation Affect Financial Reporting?. Journal of Accounting and Economics 49(1-2): 5874.

Anugrah, P. 2016. Sistem Pengendalian Internal: BPK Audit Khusus 21 BUMN.

https://finansial.bisnis.com/read/20160607 /9/555111/sistem-pengendalian-internalbpk-audit-khusus-21-bumn. Bisnis.com. Diakses tanggal 5 April 2017.

Arens, A. A., R. J. Elder, dan M. S. Beasley. 2012. Auditing and Assurance Services: An Inte-grated Approach. Fourteenth Edition. Pearson.

Ashbaugh-Skaife, H., D. W. Collins, W. R. Kinney Jr, dan R. LaFond. 2008. The Effect of SOX Internal Control Deficiencies and Their Remediation on Accrual Quality. The Accounting Review 83(1): 217-250.

Ashbaugh-Skaife, H., D. W. Collins, W. R. Kinney Jr, dan R. LaFond. 2009. The Effect of SOX Internal Control Deficiencies on Firm Risk and Cost of 
Equity. Journal of Accounting Research 47(1): 1-43.

Borisova, G., P. Brockman, J. Salas, dan A. Zagorchev. 2012. Government Ownership and Corporate Governance: Evidence from the EU. Journal of Banking E Finance 36(11): 1-46.

Beatty, A., L. Scott, dan J. Weber. 2010. Financial Reporting Quality, Private Information, Monitoring, and the Lease-versus-Buy Decision. The Accounting Review 85(4): 1215-1238.

Bedard, J. 2006. Reported Internal Control Deficiencies and Earning Quality. Working Paper. Universite Laval.

Biddle, G. dan G. Hilary. 2006. Accounting Quality and Firm-Level Capital Investment. The Accounting Review 81: 963-982.

Biddle, G. C., H. Gilles, dan S. V. Rodrigo. 2009. How Does Financial Reporting Quality Relate To Investment Efficiency?. Journal of Accounting and Economics 48: 112-131.

Blanchard, O., F. Lopez-de-Silanez, dan A. Shleifer. 1994. What do Firms do With Cash Windfalls?. Journal of Financial Economics 36: 337-360.

Bushman, R. dan R. Indjejikian. 1993. Shareholder Demand for "Distorted" Accounting Disclosures. The Accounting Review 68: 765-782.

Bushman, R. dan A. Smith. 2001. Financial Accounting Information and Corporate Governance. Journal of Accounting and Economics 31: 237-333.

Butar-Butar, S. 2015. Dampak Kualitas laporan Keuangan, Regulasi Pengendalian Internal dan Keterbatasan Keuangan Terhadap Inefisiensi Investasi. Jurnal Akuntansi dan Keuangan 7(1): 57-70.

Chalmers, K., D. Hay, dan H. Khlif. 2018. Internal Control in Accounting Research: A Review. Journal of Accounting Literature. In Press. 1-24.

Chang, X., S. Dasgupta, dan G. Hilary. 2009. The Effect of Auditor Quality on
Financing Decisions. The Accounting Review 84: 1085-1117.

Chen, T., L. Xie, dan Y. Zhang. 2017. How Does Analysts' Forecast Quality Relate to Corporate Investment Efficiency?. Journal of Corporate Finance 43: 217240.

Cheng, M., D. Dhaliwal, dan Y. Zhang. 2013. Does Investment Efficiency Improve After the Disclosure of Material Weakness in Internal Control over Financial Reporting?. Journal Of Accounting and Economics 56: 1-18.

Chung, H. H., J. P. Wynn, dan H. Yi. 2013. Litigation Risk, Accounting Quality, and Investment Efficiency. Advances in Accounting Incorporating Advances in International Accounting 29: 180-185.

Dhaliwal, D. S., O. Z. Li, A. Tsang, dan Y. G. Yang. 2011. Voluntary Nonfinancial Disclosure and the Cost of Equity Capital: The Initiation of Corporate Social Responsibility Reporting. The Accounting Review 86(1): 59-100.

Doyle, J., W. Ge, dan S. McVay. 2007. Accruals Quality and Internal Control over Financial Reporting. The Accounting Review 82(5): 1141-1170.

Fontanella, A., S. Utama, dan C. Djakman. 2014. Analisis Ketepatwaktuan Pengakuan Rugi (Loss Recognition Timeliness) pada Perusahaan BUMN di Prosiding Indonesia. Simposium Nasional Akuntansi XVIII Medan.

Ghozali, I. 2012. Aplikasi Analisis Multivariate dengan Program SPSS. Badan Penerbit Universitas Diponegoro. Semarang.

Gomariz, M. F. C. dan J. P. S. Ballesta. 2014. Financial Reporting Quality, Debt Maturity, and Investment Efficiency. Journal of Banking and Finance 40: 494506.

Healy, P. dan K. Palepu. 2001. Information Asymmetry, Corporate Disclosure, and the Capital Markets: A Review of the Empirical Disclosure Literature. Journal of Accounting and Economics 31: 405-440. 
Hogan, C. dan M. Wilkins. 2005. Do Internal Control Weakness Result in Lower Earnings Quality? Implications and Evidence from the Audit Risk Model. Working Paper. Southern Methodist University.

Holmstrom, B. dan J. Tirole. 1993. Market Liquidity and Performance Monitoring. Journal of Political Economy 101: 678-709.

Houcine, A. 2017. The Effect of Financial Reporting Quality on Corporate Investment Efficiency: Evidence from the Tunisian Stock Market. Research in International Business and Finance 42: 321-337.

Jaehong, L., C. Eunjung, dan C. Hyunjung. 2016. The Effect of Internal Control Weakness on Investment Efficiency. The Journal of Applied Business Research. 32(3): 649-662.

Jensen, M. 1986. Agency Costs of Free Cash Flow, Corporate Finance, and Takeovers. American Economic Review 76: 323-329.

Jensen, M. C. dan W. H. Meckling. 1976. Theory of the Firm: Managerial Behavior, Agency Costs and Ownership Structure. Journal of Financial Economics 10: 305-360.

Ji, Xu-Dong, Lu, W. dan W. Qu. 2017. Voluntary Disclosure of Internal Control Weakness and Earnings Quality: Evidence from China. The International Journal of Accounting 52: 27-44.

Kanodia, C., dan D. Lee. 1998. Investment and Disclosure: The Disciplinary Role of Periodic Performance Reports.
Journal of Accounting Research 36: 3355.

Keputusan Menteri Negara Badan Usaha Milik Negara Nomor: Per-01/MBU/ 2011 tentang Penerapan Tata Kelola Perusahaan Yang Baik (Good Corporate Governance).

Lambert, R. 2001. Contracting Theory and Accounting. Journal of Accounting and Economics 32: 3-87.

Lambert, R., C. Leuz, dan R. Verrecchia. 2007. Accounting Information, Disclosure, and the Cost of Capital. Journal of Accounting Research 45: 385420.

Leuz, C. dan R. Verrecchia. 2000. The Economic Consequences of Increased Disclosure. Journal of Accounting Research 38: 91-124.

Liu, X., R. Saidi, dan M. Bazaz. 2014. Instituional Incentive an Earning Quality: The Influence of Government Ownership in China. Journal of Contemporary Accounting $\mathcal{E}$ Economics 10(3): 248-261.

Peraturan Nomor VIII.G.11 Tentang Tanggung Jawab Direksi Atas Laporan Keuangan oleh Badan Pengawas Pasar Modal dan Lembaga Keuangan (BapepamLK) Tahun 2003.

Scott, W. R. 2009. Financial Accounting Theory. Fourth Edition. Prentice Hall.

Undang-Undang Nomor 19 tahun 2003 tentang Badan Usaha Miliki Negara.

Verrecchia, R. 2001. Essays on Disclosure. Journal of Accounting and Economics 32: 91-180.

Watts, R. dan J. Zimmerman. 1986. Positive Accounting Theory. Engelwood Cliffs. NJ: Prentice Hall. 